\title{
Milk Handling Practice and Awareness on Milk-Borne Diseases among Farmers of Mendefera Dairy Cooperative Union, Eritrea 2019
}

\author{
Medhanie Weldegergis Weldekidan, Michael Semere, Lwam Tesfaldet, Natnael Tesfamariam, \\ Feven Ygzaw, Aron Rezene* \\ Asmara College of health sciences
}

*Corresponding Author: Aron Rezene, Asmara College of health sciences, Email: aronrezene19@ gmail.com

\begin{abstract}
Background: Milk-borne diseases have been spread by contamination of milk through unhygienic handling of dairy workers, unsanitary milk utensils, flies and polluted water supplies. So this was prepared to assess hygienic handling practices of milk throughout the milk chain system and awareness of milk borne diseases among the personnel involved in the milk chain system in Mendefera dairy farmers cooperative union.
\end{abstract}

Methodology: A cross sectional study was carried out among Mendefera dairy farmers cooperative union from January to April 2019. Two hundred eighty seven farmers were selected randomly and all the milk handlers at the milk shops and collection Centre were included in this study. Data was gathered using pretested questionnaire and checklist for observation in the barns, collection Centre and milk shops. Finally data was analyzed using SPSS v.22.

Result: The findings of this study showed $67.2 \%$ of the farmers and $88.9 \%$ MHs wash their hands before and after handling milk. About $87.5 \%$ of the farmers use narrow necked plastic containers to transport milk to the collection Centre. And only $4.2 \%$ deliver their milk to collection site within two hours after milking is done. On the other hand, $46.4 \%$ of the farmers and 44.4\% of the MHs are aware of MBDs. At the time of observation, none of the milk handlers had covered their hair. In $61.7 \%$ of the barns, the floor was concrete and easily cleanable and only 30\% of the farmers had separated milking area from the cowshed. The two milk shops are adjoined with a toilet. Multivariate logistic analysis identified sex and educational level being independently associated with udder washing practices pre-milking. Whereas age, work, experience, and sex were significantly associated with awareness on milk-borne diseases.

Conclusion: This study concluded that awareness on milk borne diseases was poor and the hygienic practices of the personnel involved in the milk chain system in Mendefera dairy farmers cooperative union were relatively good.

Keywords: Mendefera dairy farmers, milk handlers, milk-borne diseases

\section{INTRODUCTION}

Milk is categorized among foods that are ranked at first place as it is a vital choice for humans from birth to senility. It is a better food choice not only of its good sensory properties but also its nutritional value in preventing or reducing risks of many nutritional deficiency diseases [1]. Milk consists mainly of water and the total milk solids; these are the sum of fat, protein, lactose and minerals which are the main nutritional foods that the body require to function properly [2]. Worldwide, dairy farms produced about 730 million tonnes of milk in 2011, from 260 million dairy cows [3, 4].Throughout the world, there are more than six billion consumers of milk and milk products and over 750 million people live within dairy farming households [5].

Moreover, as all foods have the potential to cause food borne illness; milk and milk products are no exception [6]. Milk is a good growth medium for many microorganisms because of its high water content, nearly neutral $\mathrm{pH}$, and variety of available essential nutrients [7]. And it can be contaminated at any point in the milk value chain. So it is the responsibility of the milk producers to identify these points and implement control measures to protect milk from contamination [8]. Good milk hygiene gives dairy products that are safe for human consumption, and that have good keeping 
quality. On the other hand, poor milk hygiene leads to spoiled products, product recalls (hence adverse publicity), food-borne diseases and unsatisfactory or declining product image $[8,9]$. The key sources of milk contamination are: faeces from soiled animals, bacteria from poor milking practices, failure to detect abnormal milk mastitis pathogens, foreign bodies especially from perished components in milking machines and bulk tanks [9]. Low income countries are significantly suffering from milkborne diseases. The increased number in owners of small dairy farming households is also aggravating the problem, this is because most of the time they use informal market channel in order to meet the needs of public without full microbial investigation [10].

The burden of Zoonotic diseases estimates about $61 \%$ of the human infection [11] and about $90 \%$ the dairy linked diseases are because of pathogens found in milk [12]. Some of the microbial contaminants are responsible for milk spoilage while others are pathogenic with potential health effects which cause milk-borne diseases [13]. These cause several milk-borne zoonotic diseases in the human population with brucellosis, tuberculosis, leptospirosis, and campylobacteriosis [14]. The common raw milk pathogenic bacteria contaminants include: Brucellaabortus, Mycobacterium bovis, Campylobacter spp., Coxiellaburnetii, Leptospira. Listeriamonocytogene, Yersinia enterocolytica, Shiga toxin producing E. coli, Staphylococcus aureus, Salmonella spp., and Clostridium spp. [15]. In Eritrea yet there in no any documented data on milk handling practices and awareness of MBDs. So, this study was designed to assess the awareness and safe handling practices of milk among the personnel of the Mendefera dairy farmers union so that to set educational training to the milk producers on safe handling of milk during milking, collection, storage, transportation and distribution.

\section{Methodology}

\subsection{Study Setting and Study Population}

The study was conducted in Mendefera dairy farmers cooperative union $54 \mathrm{Km}$ from Asmara to the South. Mendefera, the capital city of the Debub zone is a temperate place which is 1972 meters above sea level and has a population of about 50,000. The Mendefera dairy cooperative was established as an association in $15^{\text {th }}$ January 1996 under the shelter of Ministry of Agriculture, Debub zone. The union encompasses 950 dairy farmers and 9 milk handlers in their two milk shops that are located inside the city of Mendefera and one collection centre located near Adi-wegri secondary school, $1 \mathrm{~km}$ to south. The union produces about 10,000 litres per day which is directly distributed to the two shops located there and is believed to meet the needs of the public. Quality control for the raw milk is done on the basis of the laboratory procedure daily on every sample at the collection centre. The quality control procedure includes ethylene blue reduction test and lactometer test. After the quality of the milk is assured, it is kept in refrigerator at $4^{\circ} \mathrm{C}$. In this study about 287 dairy farmers and all the milk handlers at the milk shops and collection centre were included.

\subsection{Study Design}

The study was a cross sectional study designed to assess milk handling practice and the awareness on MBDs among the personnel involved in the milk chain system in Mendefera dairy farmers co-operative union from January to April 2019.

\subsection{Sample Size and Sampling Technique}

Multistage stratified random sampling method was used. The raw milk for Mendefera dairy farmer's cooperative union is provided by a total of thirty-six villages, of which twelve villages were selected randomly. Out of these twelve villages two hundred eighty seven farmers were selected using the sample size formula; [16].

$\mathrm{N} 1=\mathrm{z}^{2} \mathrm{pq} / \mathrm{d}^{2}$

Where $n 1=$ calculated sample size

$\mathrm{Z}=$ population normal standard deviation

$\mathrm{P}=$ proportion (prevalence) good handling milk and knowledge on MBDs

$\mathrm{Q}=1-\mathrm{p}$

$\mathrm{D}=$ precision

And all the milk handlers in the milk shops and collection Centre were included in this study.

\subsection{Data Collection Tools}

Data was collected using pretested questionnaire and checklist for observation both in the barns and milk shops. The questionnaires encompassed questions to assess the hygienic handling practices of milk and awareness of milk borne diseases among the personnel involved in the milk chain system in Mendefera dairy farmers cooperative union. The checklist included observations related to the setting of 
the milk shops, barns and collection centre. Furthermore, it also assessed Personal Protective Equipment usage and other safe milk handling practices among the milk handlers.

\subsection{Data Processing and Analysis}

All the raw data were coded, cleared and entered in Microsoft excel-2013 spread sheet. The analysis was carried out statistically using (SPSS V. 22, Chicago). Frequencies and proportions were used for the descriptive analysis; presented in tables and graphs. Differences in proportions were compared for significance using Chi-square $\left(\chi^{2}\right)$ test and Variables found having significant association in the $\chi^{2}$-test were analysed using multivariate logistic regression in order to control possible confounding variables. P-values were calculated and $\mathrm{p}<0.05$ were considered as statistically significant.

\subsection{Ethical Consideration}

This study sought ethical approval from Asmara college of Health Sciences, school of Public Health ethical review committee and the zonal branch of the ministry of agriculture. Written informed consent was obtained from the participants at Mendefera dairy farmer's cooperative union. The written informed consent clearly stated potential risks and benefits of the study and sought their voluntary participation.

\section{RESUlts}

\subsection{Socio-Demographic Characteristics of the Dairy Farmers and Milk Handlers}

From the total interviewed respondents, there were more males in dairy farms whereas there were more females in the milk shops. The Mean age of the dairy farmers and MHs were $47.5 \pm 16.2$ years and $42.4 \quad \pm 8.5$ years respectively.

\subsection{Milk Handling Practices of the Farmers}

Majority $(67.2 \%)$ of the farmers wash their hands both before and after handling milk as shown in table 1. About three- fourth $(71.4 \%)$ of the farmers practice udder washing before milking and from these who use udder drying technique, $24 \%$ of the farmers use common towel to dry the udder of the cows, $(32.6 \%)$ use individual towels for each cow, $19 \%$ using bare hands and the rest $24.4 \%$ do not use towel at all. It was found that $(86.4 \%)$ of the farmers use detergents and water to clean milk containers but $13.6 \%$ use water only. Most of the farmers (92.3\%) keep their milk for overnight and combine it with the milk they collect in the morning before it is delivered while $4.2 \%$ deliver the milk in less than two hours. It was also observed (70.4\%) of the farmers' store their milk in closed containers within the barn, $13.2 \%$ in open tank while $16.4 \%$ store in refrigerator. Another noticed fact is, around $34.8 \%$ of the farmers have non-dairy animals (dogs, donkey, hens, sheep, oxen and cats) within the farm.

Table1: socio-demographic characteristic of the farmers and milk handlers

\begin{tabular}{|c|c|c|c|c|c|}
\hline \multirow[t]{2}{*}{ Characteristics } & \multirow[t]{2}{*}{ Categories } & \multicolumn{2}{|c|}{ Dairy Farmers } & \multicolumn{2}{|c|}{ Milk handlers } \\
\hline & & Frequencies & $(\%)$ & Frequencies & $(\%)$ \\
\hline \multirow[t]{2}{*}{ Gender } & Male & 253 & 88.2 & 3 & 33. \\
\hline & Female & 34 & 11.8 & 6 & 66.7 \\
\hline \multirow[t]{4}{*}{ Age } & 20-30 years & 62 & 21.6 & 0 & 0 \\
\hline & $31-40$ years & 40 & 13.9 & 3 & 33.3 \\
\hline & 41-50 years & 36 & 12.5 & 5 & 55.6 \\
\hline & Above 50 & 149 & 51.9 & 1 & 11.1 \\
\hline \multirow[t]{5}{*}{ Educational level } & Illiterate & 18 & 6.3 & 0 & 0 \\
\hline & Primary level & 61 & 21.3 & 1 & 11.1 \\
\hline & Junior level & 109 & 38.0 & 5 & 55.6 \\
\hline & High school level & 95 & 33.1 & 3 & 33.3 \\
\hline & Collage level & 4 & 1.4 & 0 & 0 \\
\hline \multirow{3}{*}{$\begin{array}{l}\text { Work experience in } \\
\text { years }\end{array}$} & $<1$ year & 26 & 9.1 & 1 & 11.1 \\
\hline & Up to 5years & 110 & 38.3 & 2 & 22.2 \\
\hline & $>5$ years & 151 & 52.6 & 6 & 66.7 \\
\hline
\end{tabular}

Table2: Hygienic handling practices of farmers at the farm

\begin{tabular}{|l|l|}
\hline Types of practices (variables) & Frequencies \\
\hline Milker's Hand washing & $90(31.4 \%)$ \\
\hline Hand washing before milking & $4(1.4 \%)$ \\
\hline Hand washing after milking & $193(67.2 \%)$ \\
\hline Both before and after & \\
\hline
\end{tabular}


Milk Handling Practice and Awareness on Milk-Borne Diseases among Farmers of Mendefera Dairy Cooperative Union, Eritrea 2019

\begin{tabular}{|l|l|}
\hline Udder washing practices & $205(71.4 \%)$ \\
\hline Before milking & $82(28.6 \%)$ \\
\hline No washing & $49(24 \%)$ \\
\hline Udder drying technique(205) & $67(32.6 \%)$ \\
\hline Common towel & $89(43.4 \%)$ \\
\hline Separate & $249(86.8 \%)$ \\
\hline No used & $38(13.2 \%)$ \\
\hline \multicolumn{2}{|l|}{ containers washed with } \\
\hline Detergents and water & $22(7.7 \%)$ \\
\hline Water only & $217(75.6 \%)$ \\
\hline Frequency of cleaning of containers & $48(15.7 \%)$ \\
\hline Once & $12(4.2 \%)$ \\
\hline Twice & $10(3.5 \%)$ \\
\hline Three and above & $265(92.3 \%)$ \\
\hline Milk duration at the barn & \\
\hline Less than 2hrs & $47(16.4 \%)$ \\
\hline Over night & $38(13.2 \%)$ \\
\hline Overnight + morning & $202(70.4 \%)$ \\
\hline Milk storage before leaving the barn & $100(34.8 \%)$ \\
\hline Refrigerator & $187(65.2 \%)$ \\
\hline Open tank & $3.4 . \mathrm{K}$ \\
\hline Closed tank & \\
\hline Presence of non-dairy animals & \\
\hline Yes & \\
\hline No &
\end{tabular}

\subsection{Milk Handling Practices of the Mhs at the Milk Shops and Collection Centre \\ 3.4. Knowledge of the Farmers and Mhs about the Mbds}

Majority $(88.9 \%)$ of the MHs wash their hand before and after handling milk with $77.8 \%$ of them use detergent to wash their hand. In addition, about $77.8 \%$ of the MHs disinfect the milk equipment but $22.2 \%$ do not practice it. Few $(11.1 \%)$ of the MHs said that they give the leftover milk to the workers but the remaining said that they store it in refrigerator to use in the following day. One of the good habits of the union is that all of the milk handlers attend general medical check-up every three months. About $62.7 \%$ of the farmers and $88.9 \%$ of the MHs stop handling milk when they get sick, $24.4 \%$ of the farmers and $11.1 \%$ of the MHs said it depends on the severity of the disease, however, $12.9 \%$ of the farmers continue milk handling even they are sick.

Less than half $(46.4 \%)$ of the farmers and (44.4\%) MHs have knowledge about MBDs. Most of the farmers citied TB (62.7\%), brucellosis (1.5\%), TB + brucellosis (23.9\%), $\mathrm{TB}+$ brucellosis + leptospirosis $(10.4 \%)$ and others $(1.5 \%)$ as the most MBDs. TB was seen to be the most recognized MBDs by both of the farmers and MHs.

Few of the farmers and MHs consumption of row milk, unwashed hands, unhygienic containers and flies think as the most common mode of transmission of MBDs. More than 50\% of the farmers and MHs have received training regarding safe milk handling and the health burdens of MBDs as shown in table-3.

Table3: knowledge of farmers and MHs concerning MBDs

\begin{tabular}{|l|l|l|}
\hline \multicolumn{1}{|c|}{ Types of variables (categories) } & \multicolumn{1}{|c|}{ Farmers } \\
\hline Knowledge of MBDs & $134(46.7 \%)$ & $4(44.4 \%)$ \\
\hline Have knowledge & $153(53.3 \%)$ & $5(55.6 \%)$ \\
\hline Haven't knowledge $\quad(n=4)$ & $2(50 \%)$ \\
\hline Types of MBDs (n=134) & $84(62.7 \%)$ & 0 \\
\hline TB & $2(1.5 \%)$ & 0 \\
\hline Brucellosis & $32(23.9 \%)$ & $2(50 \%)$ \\
\hline TB + brucellosis & $14(10.4 \%)$ & 0 \\
\hline TB + brucellosis + leptospirosis & $2(1.5 \%)$ & \multicolumn{1}{|c|}{$(\mathrm{n}=4)$} \\
\hline Others & $4(3 \%)$ & 0 \\
\hline Mode of transmission $(\mathrm{n}=134)$ & \multicolumn{1}{|c|}{} \\
\hline Flies &
\end{tabular}


Milk Handling Practice and Awareness on Milk-Borne Diseases among Farmers of Mendefera Dairy Cooperative Union, Eritrea 2019

\begin{tabular}{|c|c|c|}
\hline unhygienic containers & $16(11.9 \%)$ & 0 \\
\hline Unwashed hands & $10(7.5 \%)$ & 0 \\
\hline Row milk consumption & $20(14.9 \%)$ & $1(25 \%)$ \\
\hline Mentioned more than one & $84(62.7 \%)$ & $3(75 \%)$ \\
\hline \multicolumn{3}{|l|}{ Training received } \\
\hline Yes & $144(50.2 \%)$ & $7(77.8 \%)$ \\
\hline No & $143(49.8 \%)$ & $2(22.2 \%)$ \\
\hline
\end{tabular}

\subsection{Observation of the Barn/Farm, Milk} Shops and Collection Centre

\subsubsection{Hygienic Practices of the Farm, Milk Shops and Collection Center}

Most of the farmers contain ventilated barn with $61.7 \%$ of the barn made of concreted floor while the remaining $38.3 \%$ with soil ground area. Additionally, $61.3 \%$ of the floor was sloppy drain while $66.6 \%$ of the cowshed floor was with non-slippery floors. $39.4 \%$ of the barn was very clean, clean (39.7\%) while 20.9 were found to be dirty. The milk shops and collection Centres were well-ventilated and concreted with clean, non-slippery and sloppy floors. Though the milk shops have wash basin, sinks with drain boards and separate dressing room, it is adjoined with toilets. In the collection Centre separate

Table4: hygienic of the milking area, milking equipment and milk containers during transportation

\begin{tabular}{|l|l|}
\hline \multicolumn{2}{|c|}{ Cleanness of milking area } \\
\hline Clean & $119(41.5 \%)$ \\
\hline Not clean & $168(58.5 \%)$ \\
\hline Manure heap away from the barn \\
\hline Yes & $169(58.9 \%)$ \\
\hline No & $118(41.1 \%)$ \\
\hline Milking area & $201(70 \%)$ \\
\hline Within the cowshed & $86(30 \%)$ \\
\hline Outside the cowshed & $10(3.5 \%)$ \\
\hline Milking equipment & $248(86.4 \%)$ \\
\hline Aluminum & $29(10.1 \%)$ \\
\hline Plastic & $8(2.8 \%)$ \\
\hline Bucket & $253(87.5 \%)$ \\
\hline Milking containers during transportation \\
\hline Aluminum & $28(9.8 \%)$ \\
\hline Narrow neck plastic & \\
\hline Bucket & \\
\hline
\end{tabular}
with drain boards were all absents.

\subsubsection{Hygienic Conditions of Milking Area and Milk Containers at Barn and During Transportation}

About $58.5 \%$ of the milking areas were not clean with a manure heap inside accounting a $58.9 \%$ of the milking area. Majority (70\%) of the farmers milking area were within the cowshed while $30 \%$ outside the cowshed. Only $3.5 \%$ of the farmers use aluminium for milking, $86.4 \%$ plastic and $10.1 \%$ use bucket. Majority $(87.5 \%)$ of the farmers use narrow necked plastic containers for transportation to the collection Centre, bucket (9.8\%) whereas $2.8 \%$ use aluminium containers as seen intable- 4 . toilets were observed but wash basin and sinks at the Milk Shops and Collection Centre

Majority (88.9\%) of the MHs do not wear apron or gown at the milk shops while $11.9 \%$ practices apron or gown wearing. In addition, all of milk handlers do not cover their hairs and wear hand gloves. However, all of the milk handlers wear coveralls at the milk shops and collection Centre. About $88.9 \%$ of the milk handlers were observed fetching milk using a cup with dipper but the remaining $11.9 \%$ uses a cup without dipper.
A multivariable logistic regression analysis shows that the male dairy farmers were eight times more likely to wash the udder of the cows as compared with females ( $\mathrm{AOR}=8.58 ; 95 \%$ CI:1.97-3.37), $\mathrm{P}<0.005)$. The illiterate dairy farmers were three times more likely to wash the udder of the dairy cattle than the literate dairy farmers $(\mathrm{AOR}=3.43$; 95\% CI; 1.25-9.43), $\mathrm{p}<0.05)$. The knowledge of the respondents on MBDs was significantly associated with gender, age and working experiences of the dairy farmers. Male responders have $63 \%$ less knowledge on the MBDs as compared with female respondents $(\mathrm{AOR}=0.37$; $95 \% \mathrm{CI}$; 0.17- 
$0.82), \mathrm{p}<0.05)$. The respondents whose age $\leq 30$ years old twice more likely to have knowledge on the milk-borne diseases as compared with the farmers whose age is above 30years (AOR=2.37; 95\%CI; 0.17-0.82), $<\mathrm{p}=0.05)$.

Table5: Variables associated with hand washing, udder washing and knowledge on MBDs of the dairy farmers

\begin{tabular}{|l|l|l|l|l|l|l|}
\hline \multicolumn{1}{|c|}{ Independent } & Hand washing & & \multicolumn{2}{c|}{ Udder washing } & \multicolumn{2}{c|}{ Knowledge on MBDs } \\
\cline { 2 - 8 } & \multicolumn{1}{c|}{ OR(95CI) } & P value & \multicolumn{1}{|c|}{ OR(95\%CI) } & P value & OR(95\%CI) & P value \\
\hline Sex & & & & & & \\
\hline Male & $3(0.6-3.9)$ & 1.23 & $8.58(1.97-3.37)^{*}$ & 0.004 & $0.37(0.17-0.82)^{*}$ & 0.014 \\
\hline Female & 1 & & 1 & & 1 & \\
\hline Age & & & & & & \\
\hline$\leq 30$ & $0.23(0.2-12.1)$ & 0.995 & $1.33(0.67-28)$ & 0.401 & $2.37(1.29-4.34)^{*}$ & 0.005 \\
\hline$>30$ & 1 & & 1 & & 1 & \\
\hline Educational level & & & & & & \\
\hline Illiterate & $1.56(0.2-2.36)$ & 0.993 & $3.43(1.25-9.43)^{*}$ & 0.017 & $2.006(0.72-5.603)$ & 0.184 \\
\hline Literate & 1 & & 1 & & 1 & \\
\hline Work experience & & & & & & \\
\hline$\leq 1$ yrs & $0.26(0.52-6.7)$ & 0.58 & $0.76(0.433-1.335)$ & 0.066 & $2.96(1.19-7.36)^{*}$ & 0.020 \\
\hline Up to 5yrs & $2.6(0.89-11.91)$ & 0.69 & $0.35(0.112-1.073)$ & 0.339 & $1.26(0.76-2.100)$ & 0.366 \\
\hline$>5$ yrs & 1 & & 1 & & 1 & \\
\hline
\end{tabular}

$*=p<0.05$

\section{DISCUSSION}

This study was seated to assess the hygienic milk handling practices among the dairy farmers and MHs and their knowledge on milk-borne diseases. Microbial analysis was out of scope of this study, but it was assured that the milk produced was inclined to microbial contamination during pre and post-harvesting milk handling practices, prolonged storage duration and transportation to the collection center. It is indorsed that the dairy farmers before milking should clean barn, wash and dry the udder with clean towels regularly on the daily basis. Teat dipping with appropriate disinfectant after milking is important to prevent entry from harmful microorganisms [17]. In this study, it was observed that milking was done at the site of the cowshed with manure heap nearby, sloppy floor and presence of non-dairy animals within the farm.

Majority of the farmers $65.9 \%$ clean their barns daily while $32.8 \%$ clean their barn three times a week but the remaining $1.3 \%$ clean their barn five times a week. And this result is almost similar with result reported from Addis-Ababa Ethiopia [18], 74\% of the respondents cleans their floor daily. But different result was reported by [19], 47\% of the farmers clean their barn three times a week. In addition to this $30 \%$ of the dairy farmers have separate milking area but $70 \%$ milked within the cowsheds or parlors. Similar results were reported from Turkey [20]
Farmers whose working experience $\leq 1$ years have twice more knowledge than those work greater than one year $(\mathrm{AOR}=2.96 ; 95 \% \mathrm{CI} ; 1.19$ 7.36), $\mathrm{p}<0.05$ ) (show table 5). with $30 \%$ of the dairy farmers separated milking area. In this study, $67.2 \%$ of the farmers (milkers) wash their hand before and after milking. While the MHs at the milk shops and collection Centre in the study area did not wear apron or gown, cover their hair and gloves were not practiced during milk handling which is similar to [18].

Washing teats and udder of dairy cows before milking is one of the most impressive hygienic practices prerequisite to ensure safe milk production. Because the teats and udder of the dairy cows have direct contact with the ground, urine, dung and feed remnants. Clean animals are more likely to remain disease free and at milking time, are less likely to contaminate the milk with harmful bacteria [21]. As a result, this study revealed that $71.4 \%$ of the dairy farmers wash the udder of their cow before milking but $28.6 \%$ do not practice udder washing before milking. A higher result was reported by [22], which is $85.2 \%$ of small size farm owning households in Hawassa city wash the udder of the dairy cow before milking. Opposing to this result [21] it was reported that the entire respondent did not practice pre milking udder washing. And also contrary results reported by [23] from Ghana who reported about $92 \%$ of the respondents did not wash the teats of their cow. Drying of teats and udder of the dairy cow with clean individual towels following cleaning practices during milking is essential for quality milk production [17]. During this study, 24\% of 
the farmers used common towel to dry the teats and udder of the cow, $32.6 \%$ used separate towel for each cow. Comparable to this result reported by [24], about $48 \%$ of the respondents failed to use towel after washing the udder, $44 \%$ used common towel while $3.8 \%$ used separated towel for each cow. Contrary results were reported by [25], that $83.2 \%$ of the respondents failed to dry the udder of the cow after washing. Narrow necked plastic containers are not easily washed especially in the inner corners and this leads to sticking of milk residues. In such a situation, microorganisms can rapidly build up milk residues in milk storage containers, and may contaminate the milk on subsequent uses [26-28].In spite of their high value, aluminum containers are recommended because they do not have adhesive properties and are easy to clean [29]. In the current study, majority $(75.6 \%)$ of the farmers wash their equipment two times between each milking practices. In addition, $86.5 \%$ of the farmers use detergent with water to clean their equipment which was found to be similar with a study reported by [30]. About $11.1 \%$ of the farmers' used aluminum while $88.9 \%$ of them used narrow necked plastic containers (Jerrycan) for storing and transporting the milk to the milk collection center. A study from Tanzania revealed that none of the farmers used aluminum containers to transport their milk to the collection centers [26].

Milk delivered to milk collection Centers directly after milking has less chance of contamination and must reach the collection Centre within 2-3 hours [31]. Milk kept in refrigerator between $2^{0} \mathrm{c}-8^{0} \mathrm{c}$ has an essential role to minimize bacterial multiplication [9]. According to the current findings, only $4.2 \%$ of the dairy farmers transport their milk to the collection center directly after milking unlike the results reported by [32] who found $100 \%$ of the farmers transport their milk directly to the collection station.

The finding of this study reveals that about $12.9 \%$ of the farmers continue to milk even they are sick. These finding coincide with other studies on the same fields in Vietnam [32]. However, reports in Tanzania [26] showed that all of the milk retailers stopped milk handling when they get sick.

Even though the union gives training regarding MBDs, the findings of this study showed that their knowledge on MBDs was poor. Less than half of the dairy farmers and MHs of this study were aware of the general MBDs. $84.6 \%$ the farmers and $50 \%$ of the MHs explained TB as one of the MBDs. Concurrent findings were reported from Zimbabwe [33] and Tanzania [26] in regard to the knowledge and awareness of MBDs. In addition to this, some of those farmers who have knowledge on MBDs were able to mention the common mode of transmission of MBDs.

The floors of the milk shops and the collection centers were smooth which provides ease during cleaning in order to reduce cross contamination of milk. But the milk shops were adjoined to toilets and do not have smooth walls and washbasins as well. To conclude, the milk collection Centre of Mendefera dairy farmers association has similarities with the milk collection Centre of Zambia [34] and England [9] in infrastructure of the milk collection centers.

\section{CONCLUSION}

This study showed that the hygienic practices of handling milk among the farmers and milk handlers at the milk shops and collection Centre was good, however, there was no adequate awareness on MBDs and their mode of transmission. Majority of them wash and disinfect their equipment and maintain their personal hygiene which is an indicator of their mind-set in preventing MBDs. This study recognizes that training and guidance about all the precautions which should be taken consistently throughout the milk chain system are necessary for the farmers and the milk handlers at the milk shops and the collection Centre in order to reduce microbial contaminations and entrance of foreign particles. And this should be corrected as it is required for the protection of milk from direct or indirect contamination.

\section{ACKNOWLEDGMENTS}

The authors are grateful to Asmara College of Health science, Eritrea and study participants who spent their valuable time responding to the questionnaire accordingly. In addition, we thank Mr. Yonatan Mehari for his immense participation and co-operation during paper work.

\section{REFERENCE}

[1] Kalkwarf HJ, Khoury JC, Lanphear BP. Milk intake during childhood and adoulescence, adult bone densit and osteoporotic fracture in US women. Am J ClinNutr2003; 77(1):10e1.

[2] Manual on milk safety, quality and hygiene may 2011g.s pandey 
[3] Food and Agriculture Organization of the United Nations. May 2012. pp. 8, 51-54.

[4] "World Dairy Cow Numbers". [FAO]. January 14, 2014. Retrieved March 23, 2014.

[5] $\uparrow$ Hemme, T. and Otte, J., ed. (2010). Status and Prospects for Smallholder Milk Production: A Global Perspective. Food and Agriculture Organization of the United Nations.

[6] Code of hygienic practice for milk and milk products (CAC/RCP 57-2004)

[7] Handling Practices and Microbial Quality of Raw Cow's Milk Produced and Marketed in Shashemene Town, Southern EthiopiaTeshome Gemechu1*, Fekadu Beyene2 and Mitiku Eshetu3 20141

[8] A training guide for small scale milk traders inSomalia fao 2018

[9] A Practical guide for milk producers (2004) by food standard agency. Food.gov.uk

[10] Improving milk safety at farm-level in an intensive dairy production system: relevance to smallholder dairy producers Habtamu Lemma D.,AshenafiMengistu, Taddese Kuma, and Berhanu Kuma

[11] Taylor, L.H., Ltham, S.M., Wopolhouse, M.E., 2000. Risk factors for human disease emergence. Transactions of Royal London Society of Biological Sciences, 356, 983--989.

[12] Shirima GM, Kazwala RR, Kambarage DM (2003). Prevalence of bovine tuberculosis in cattle in different farming systems in the eastern zone of Tanzania. J. Prev. Vet. Med. 57:167-172.

[13] Oliver SP, Boor KJ, Murphy SC, Murinda SE. Food safety hazards associated with consumption of raw milk. Food borne Pathog Dis. 2009; 6:793-806.

[14] Sivapalasingams, S., Friedman, C.R., Cohen, L. and Tauxe, R.V. (2004). Fresh produce: a growing cause of outbreaks of foodborne illness in the United States.

[15] Newell DG, Koopmans M, Verhoef L, Duizer E, Aidara-Kane A, Sprong H, et al. Food-borne diseases - the challenges of 20years ago still persist while new ones continue to emerge. Int $\mathrm{J}$ Food Microbiol. 2010; 139(Suppl 1):S3-15

[16] Daniel, 1999) Biostatistics: a foundation for analysis in the health sciences. th $^{\text {th }}$ edition new york, john Wiley and sons .Macfarlane SB (1997): conducting a descriptive survey 2. Choosing a sampling strategy,27(1): 14-21

[17] Zelalem Y (2010) Quality factors that affect Ethiopian milk business: Experiences from selected dairy potential areas. Netherlands Development Organization, Addis Ababa, Ethiopia

[18] FufaAbunna, NigusTasew, FikruRagassa, Dinka Ayana, KebedeAmenu. Handling
Practices, Quality and Safety of Milk along the Dairy Value Chains in Selected Sub Cites of Addis Ababa, Ethiopia. Biomed J Sci\& Tech Res 13(1)-2019. BJSTR. MS.ID.002330. DOI:

[19] Abebe B, Zelalem Y, Ajebu N (2012) Hygienic and microbial quality of raw whole cow's milk produced in Ezha district of the Gurage zone, Southern Ethiopia. Wudpecker Journal of Agricultural Research 1(11): 459-465.

[20] Nevin Demirbas, Figen Çukur, Özlem Yildiz, EvrenGÖlge, (2009).Level of Knowledge, Practices and Attitudes of Dairy Farmers Regarding Food Safety in Turkey. NEW MEDIT N.4/2009

[21] Kurwijila R (2006) Hygienic milk handling, processing and marketing: reference guide for training and certification of small-scale milk traders in Eastern Africa. International Livestock Research Institute, Nairobi, Kenya.

[22] Haileselassie W, Zelalem Y, Yosef T (2012) Hygienic practices and microbiological quality of raw milk Produced under different farm size in Hawassa, Southern Ethiopia. Journal of Agricultural Research 1(4): 132- 142

[23] Kennedy KwasiAddo, Gloria Ivy Mensah, Naomi Nartey, George KwasiNipah, David Mensah, Kwame George Aning, Henk Lucas Smits,(2011). (KAP) of Herdsmen in Ghana respect to Milk-Borne Zoonotic Diseases and the Safe Handling of Milk J.Basic Appl.Sci. Res., 1(10)1556-1562

[24] Haile W., Zelalem Y. and Yosef T.G. (2012). Hygienic practices and microbiological quality of raw milk produced under different farm size in Hawassa, southern Ethiopia. Wud pecker Research Journals .Agricultural Research and Reviews Vol. 1(4), pp. 132 - 142, May 2012. Available online athttp: //www. Woodpecker researchjournals.org/ARR

[25] Tsegay Lijalem, Gebreegziabher Zereu,(2015), Hygienic Milk Handling and Processing at Farmer Level in Wolaita Zone, Southern Ethiopia. Food Science and Quality Management www.iiste.org. Vol.41, 2015

[26] Fortunate Shija. (2013) Assement of Milk Handling Practices And Bacterial Contaminationsalong the Dairy value chain and food safety of SokoineUniveristy of Agriculture

[27] Kivaria, F.M., Noordhuizen, J.P.T.M. and Kapanga, A.M. (2006). Evaluation of thehygienic quality and associated public health hazards of raw milk marketedby smallholder dairy producers in the Dar es Salaam region, Tanzania. Journal of Tropical Animal Health Production, 38: 185-194.

[28] Bukuku, J.N. (2013). Health risks awareness due to raw milk consumption in Arusha cityand Meru district, Tanzania. Unpublished Dissertation for Award of MSc. Degree at 
Sokoine University of Agriculture, Morogoro, Tanzania, 91pp

[29] Karuga S (2009) Draft report on dairy chain analysis, Timau milk shed. Micro enterprise support program trust.

[30] Saba H (2015) Quality assessment of cattle milk in AdeaBerga and Ejerie districts of west shoa zone, Ethiopia. M Sc Thesis, Haramaya University, Ethiopia.

[31] Vivekan and Nalla. ( 2015), Importance of milk safety and hygiene practices in quality trend.

[32] Hayley Renee Ashbaugh,(2010) a descriptive Survey of Dairy Farmers in VinhThinh
Commune, Vietnam for the Degree Master of Public Health in the GraduateSchool of the Ohio State University.

[33] Mosalagae, D., Pfukenyi, D.M. and Matope, G. (2011). Milk producers' awareness of milkborne zoonoses in selected smallholder and commercial dairy farms of Zimbabwe. Tropical Animal Health Production, 43(3): 733-7339.

[34] G. S. Pandey.,G.C.J. Voskuil., (May 2011). Golden Valley Agricultural Research Trust. Manual on Milk Safety, Quality and Hygiene. Lusaka Zambia.

Citation: Medhanie Weldegergis Weldekidan, et. al, Milk Handling Practice and Awareness on Milk-Borne Diseases among Farmers of Mendefera Dairy Cooperative Union, Eritrea 2019. ARC Journal of Clinical Case Reports. 2019; 5(4): 13-21. doi:dx.doi.org/ 10.20431/2455-9806.0504004.

Copyright: (C) 2019 Authors. This is an open-access article distributed under the terms of the Creative Commons Attribution License, which permits unrestricted use, distribution, and reproduction in any medium, provided the original author and source are credited. 